\title{
3D PRINTING TO COMBAT THE COVID-19 PANDEMIC
}

\author{
Vitor Alberto Nascimento Souza ${ }^{a}$ Marcus V. Mendes Gomes ${ }^{a}$, \\ a , Dpt. Indústria Criativa, Centro Universitário SENAI CIMATEC, Brasil
}

\begin{abstract}
The present study aims to analyze the means of reviewing the literature, the use of 3D printing during the first months of the COVID-19 pandemic. A review used a search engine from Derwent Innovation. The results indicated six articles, of which three studies were reviews and research on online sources and three other articles that reported practical experiences of product development. According to the studies surveyed, concluded that 3D printing has great problem solving capacity and presents itself as an important option in situations where exposing quick and customized responses. Future research is needed to assess how 3D printing sees real contributing to health challenges.
\end{abstract}

Keywords: 3D printing; COVID-19; additive manufacturing.

\section{A IMPRESSÃO 3D NO COMBATE A PANDEMIA DO COVID-19}

Resumo: O presente estudo tem como objetivo analisar por meio da revisão da literatura, a utilização da impressão 3D durante os primeiros meses da pandemia do COVID-19. A revisão utilizou a ferramenta de busca da Derwent Innovation. Os resultados indicaram seis artigos, dos quais três estudos foram revisões e pesquisa em fontes online e outros três artigos que relataram experiências práticas de desenvolvimento de produto. De acordo com os estudos levantados, conclui-se que a impressão 3D possui grande capacidade de resolução de problemas e se apresenta como uma importante opção em situações onde requerem repostas rápidas e customizadas. Futuras pesquisas é necessário para avaliar de que maneira a impressão 3D veem efetivamente contribuindo nos desafios dentro da área de saúde.

Palavras-chave: Impressão 3D; COVID-19; manufatura aditiva 


\section{INTRODUCTION}

The new fast-transmitting, zoonotic virus known as COVID-19 (SARS-CoV-2), still without a vaccine [1], imposed social isolation on the world and made public health an economic issue. Even when there was an outbreak in China and its global impacts were uncertain, the economy was already fluctuating and showing signs that it would be seriously affected [2].

In the area of health, distance measures are strongly recommended by the World Health Organization (WHO) and defended by the health professionals as the virus proliferated in the world. The objective of this measure is to try to level the contamination curve, giving the government time to increase the capacity of the health systems in their regions [3]. Even, reports of shortage of inputs such as ventilators, medications and personal protective equipment (PPE) burst [4].

The efforts of public and private companies and individuals with the support of emerging technologies, such as additive manufacturing, were a milestone in the fight against the pandemic. These technologies have become important in the study of COVID-19, in the development of advanced diagnostic tools and treatments and in the response to the shortage of medical supplies [5]. The possibility that hospitals have 3D printing laboratories capable of producing new or replacement parts are important alternatives in times of difficulties such as that faced in the 2020 pandemic [6].

$3 \mathrm{D}$ printing technology as a strong ally in healthcare seems to attract the attention of the world's largest research organizations. With the aid of the search tool Derwent Innovation, a survey was carried out crossing the keywords 3D printing OR 3D bioprinting AND health* OR medical supplies, between the years 2015 and 2019 and an increasing trend of studies in this area was detected (FIGURE 1).

Figure 1. Article publishing trend

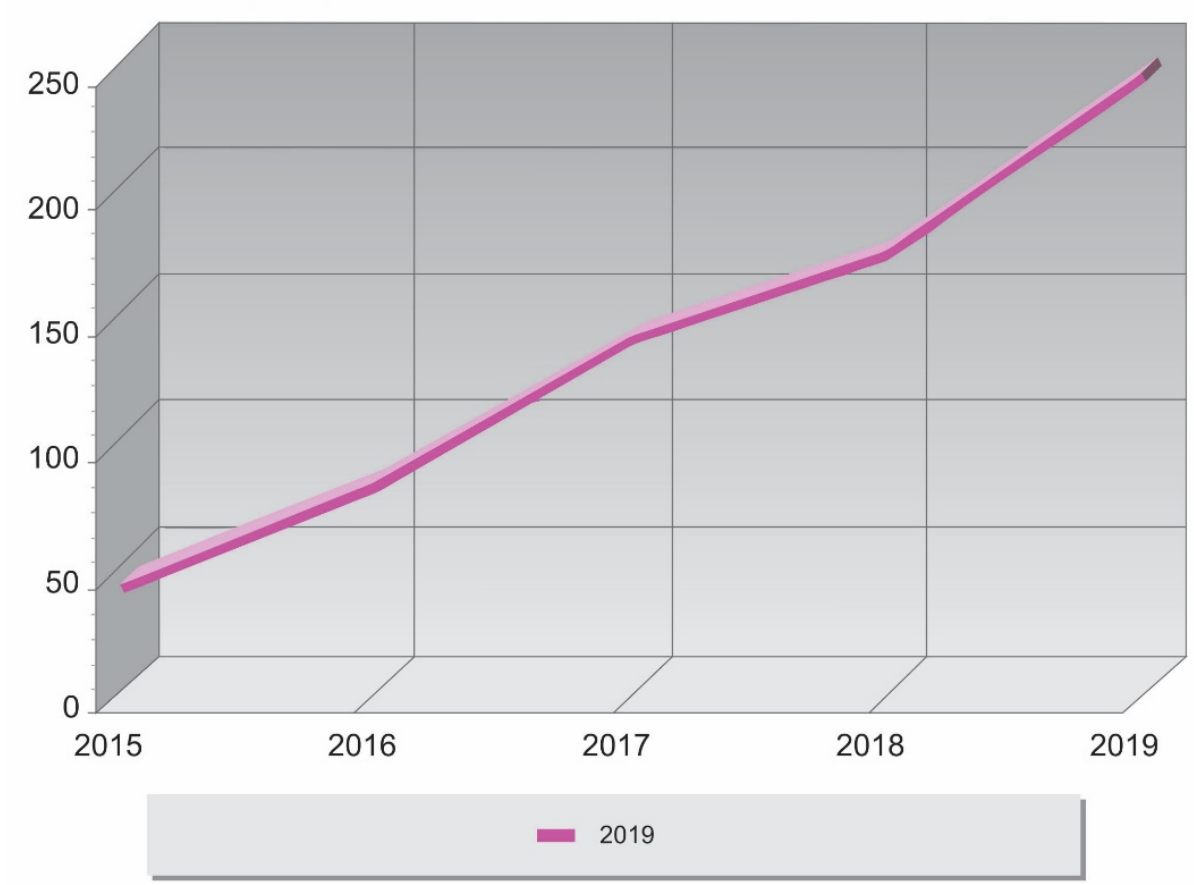

Source: Derwent Innovation. www.derwentinnovation.com 
Due to the relevance of 3D printing for the health area, already highlighted by the increase of studies in the area in the last 5 years and by showing an alternative technology to aid in the production of medical supplies in times of pandemic, the present study, therefore, has as aim to analyze, through a literature review, the use of $3 \mathrm{D}$ printing during the first months of the COVID-19 pandemic.

\section{METHODOLOGY}

The research was carried out using the Derwent Innovation search tool, which searched for articles in indexed journals in the Web of Science database, published in 2020 and in the English language. Derwent belongs to Clarivate Analytics that works with technological innovations, a patent search system and international articles.

The literature review used keywords such as $3 d$ printing $O R$ additive manufacturing OR rapid manufacturing AND covid* OR corona ADJ1 virus. The research was carried out on August 3, 2020 and returned articles published until July according to table 1. As it was not expected to find a large number of articles, a qualitative analysis was carried out, seeking to evaluate the results against the objectives of each study. Therefore, it first followed a description of the objectives and results of each study and further analysis.

\section{RESULTS AND DISCUSSION}

This literature review identified six articles (TABLE 1), of which two studies [4, 5] were reviews about the importance of emerging technology in coping with the pandemic. Another study [6] conducted a search on online sources and went deeper into technically analyzing the role of 3D printing in the pandemic. Another three articles report practical experience of product development $[7,8,9]$.

Table.1 Literature review involving 3D printing and COVID-19

\begin{tabular}{|c|c|c|c|}
\hline Authors & Country & Subject category & Date \\
\hline SALMI, Mika et al & Switzerland & $\begin{array}{c}\text { Chemistry } \\
\text { Engineering } \\
\text { Materials Science } \\
\text { Physics }\end{array}$ & JUN 2020 \\
\hline MUELLER, Tobias et al & Germany & $\begin{array}{c}\text { Chemistry } \\
\text { Engineering } \\
\text { Materials Science } \\
\text { Physics }\end{array}$ & JUN 2020 \\
\hline
\end{tabular}




\begin{tabular}{|c|c|c|c|}
\hline VAFEA, Maria Tsikala et al & USA & $\begin{array}{l}\text { Cell Biology } \\
\text { Biophysics } \\
\text { Engineering }\end{array}$ & JUN 2020 \\
\hline ERICKSON, Melissa M. et al & USA & Orthopedics & JUL 2020 \\
\hline LAMPROU, Dimitrios A. & England & Engineering & JUL 2020 \\
\hline $\begin{array}{l}\text { SWENNEN, Gwen RJ; } \\
\text { POTTEL, Lies; HAERS, Piet } \\
\text { E. }\end{array}$ & Scotland & $\begin{array}{c}\text { Dentistry, } \\
\text { Oral Surgery \& } \\
\text { Medicine } \\
\text { Surgery }\end{array}$ & MAY 2020 \\
\hline
\end{tabular}

In their study Salmi et al [6] analyzed the quantity and costs of parts that can be manufactured with a single 3D printing machine in 24 hours. The pieces that were part of the authors' studies were the face shield, which was also mentioned in the studies by Mueller et al [7], Vafea et al [4] and Erickson et al [8], the face mask, which was also the object study by Swennen, Pottel and Haers [9], the nasal swab and the venturi valve, also mentioned in [4]. Then, the authors [6] raised the possible technologies that can be used to manufacture parts such as SLA (stereolithography), FDM (fused filament deposition) also in [7] and SLS (Selective laser sintering) also in [ 9]. With all the data collected, the author demonstrates the costs associated with the production of the items and based on the number of identical 3D printers in the world, he makes a projection of the ability to act globally in this technology to face the pandemic.

The study by Mueller et al [7] reports on the whole experience of collaborative work to deal with the pandemic. The authors emphasize the importance of sharing models such as the support of the facial shield provided by PRUSA, the use of several filaments such as PLA, ABS and PETG, with emphasis on PLA for its ease of printing and absorption of shape and PETG for its mechanical resistance and possible decontamination with high temperature. For the authors, even the FDM technology that is more commercially accessible today, is an important piece of equipment to combat COVID-19.

Vafea et al [4] debate about the importance of emerging technologies in facing the pandemic. For the authors [4] the 3D printer together with other technologies such as robotics, use of nanotechnologies for vaccines, artificial intelligence, can bring faster and more personalized responses in urgent situations. Like [7], the authors [4] emphasize the importance of information sharing and collaborative work.

Erickson et al [8] proposed a customization of an existing PPE, in order to combat the scarcity of the item on the market and increase its filtration efficiency. The objective was to develop a head and neck protection helmet used in operating rooms that was robust and reliable. Because it is an item that would necessarily need to be injected, build a mold for later use. As in previous studies, the rapidity of 3D prototyping stands out. 
Lamprou [5] explores bioprinting, a more advanced solution for the use of 3D printing in the field of health, capable of treating specific diseases with a more personalized approach. Through the predictive, preventive and personalized approach (3P), using printing methods adjusted to the requirements of medical products for consumption, it is possible to take the technology of production of medicines into hospitals, accelerating the entire logistics chain associated with the supply of these medicines and allowing researchers, who also need to act on the front of the fight, to adjust doses and carry out their tests with greater speed.

The work of Swennen, Pottel and Haers [9] brings the development of an individual face mask using the SLS additive manufacturing technology. With virtualization of the user's face and subsequent modeling, it was possible to develop a customized mask in polyamide material that would allow greater resistance.

The works presented in this review, especially those that developed products $[8,9]$ responded satisfactorily to one of the challenges of 3D printing, which is to merge the capabilities of $3 \mathrm{D}$ printing with high volume yield $[10,11]$. This was possible thanks to collaborative work and the creation of Maker networks. However, the concurrent use of other resources such as the 3D scanner, used to obtain an exclusive and customizable PPE geometry, also made it possible to produce these products quickly and effectively [9]. The use of these types of technologies makes it possible to address aspects such as the need to implement controllable and biocompatible production facilities in hospitals and thus reduce the logistics chain, the production cost and increase the availability of items

\section{CONCLUSION}

From the articles found in the review, it is concluded that additive manufacturing demonstrated great problem-solving capacity in the first months of the pandemic, thanks to the possibility of working with varied raw materials and the flexibility to produce several items only with the change of your reference file. In addition, characteristics of additive manufacturing such as good accuracy, reliability and repeatability of the process had great relevance in the articles found.

In the articles that reported their practical experiences during a pandemic, the importance of collaborative work was evidenced as a way to optimize the medical parts production process in a timely manner. With the aid of standards such as cloud-based printing and other emerging technologies, 3D printing allows performance in varied scenarios, not only in situations of social isolation, but in any situation where it is necessary to have quick and customized responses. What makes 3D printing a technology that allows you to explore creative freedom and produce items with high complexity without costing your production costs.

Based on this conclusion, future research is needed to further assess how these additive manufacturing technologies, such as 3D printing, are effectively contributing within the health field, how it can contribute to new challenges and specifically about the pandemic, whether there was a contribution to the generation of patents. 


\section{REFERENCES}

${ }^{1}$ SHEREEN, Muhammad Adnan et al. COVID-19 infection: Origin, transmission, and characteristics of human coronaviruses. Journal of Advanced Research, 2020.

OZILI, Peterson K.; ARUN, Thankom. Spillover of COVID-19: impact on the Global Economy. Available at SSRN 3562570, 2020.

${ }^{2}$ RANNEY, Megan L.; GRIFFETH, Valerie; JHA, Ashish K. Critical supply shortagesthe need for ventilators and personal protective equipment during the Covid-19 pandemic. New England Journal of Medicine, v. 382, n. 18, p. e41, 2020.

${ }^{3}$ COFEN. Profissionais da saúde reclamam da falta de equipamentos de proteção individual. Available at: <http://www.cofen.gov.br/profissionais-da-saude-reclamamda-falta-de-equipamentos-de-protecao-individual_78970.html>. Accessed on: 8 aug. 2020.

${ }^{4}$ VAFEA, Maria Tsikala et al. Emerging Technologies for Use in the Study, Diagnosis, and Treatment of Patients with COVID-19. Cellular and Molecular Bioengineering, p. 1-9, 2020.

${ }^{5}$ LAMPROU, Dimitrios A. Emerging technologies for diagnostics and drug delivery in the fight against COVID-19 and other pandemics. Expert Review of Medical Devices, p. 1-6, 2020.

${ }^{6}$ SALMI, Mika et al. 3D Printing in COVID-19: Productivity Estimation of the Most Promising Open Source Solutions in Emergency Situations. Applied Sciences, v. 10, n. 11, p. 4004, 2020.

${ }^{7}$ MUELLER, Tobias et al. Eight Weeks Later-The Unprecedented Rise of 3D Printing during the COVID-19 Pandemic-A Case Study, Lessons Learned, and Implications on the Future of Global Decentralized Manufacturing. Applied Sciences, v. 10, n. 12, p. $4135,2020$.

${ }^{8}$ ERICKSON, Melissa M. et al. Helmet modification to PPE With 3D printing during the COVID-19 Pandemic at Duke University Medical Center: A novel technique. The Journal of Arthroplasty, 2020.

${ }^{9}$ SWENNEN, Gwen RJ; POTTEL, Lies; HAERS, Piet E. Custom-made 3D-printed face masks in case of pandemic crisis situations with a lack of commercially available FFP2/3 masks. International Journal of Oral and Maxillofacial Surgery, 2020.

${ }^{10}$ BAK, David. Rapid prototyping or rapid production? 3D printing processes move industry towards the latter. Assembly Automation, v.23, n.4, p. 340-345, 2003.

${ }^{11}$ BEN-NER, Avner; SIEMSEN, Enno. Decentralization and localization of production: The organizational and economic consequences of additive manufacturing (3D printing). California Management Review, v. 59, n. 2, p. 5-23, 2017. 